DOI:10.17951/h.2020.54.1.19-29

\begin{tabular}{lcc}
\hline & A N N A L E S \\
UNIVERSITATIS MARIAE CURIE-SKŁODOWSKA \\
LUBLIN - POLONIA \\
SOL. LIV, 1 & SECTIO H \\
\hline
\end{tabular}

\author{
PAWEŁ DEC \\ paweldec@gmail.com \\ Warsaw School of Economics \\ 162 Niepodległości Av., 02-554 Warsaw \\ ORCID ID: https://orcid.org/0000-0001-8460-2591 \\ PIOTR MASIUKIEWICZ \\ piotr.masiukiewicz@wp.pl \\ Warsaw School of Economics \\ 162 Niepodległości Av., 02-554 Warsaw \\ ORCID ID: https://orcid.org/0000-0003-0686-5024
}

\title{
Public and Legal Burdens on Cooperative Banks and Limits of the Financial Strength of Taxes
}

Keywords: cooperative banks; tax strength; tax burdens; legal charges; bank fees; bank tribute

JEL: G21; G32; G33

How to quote this paper: Dec, P., \& Masiukiewicz, P. (2020). Public and Legal Burdens on Cooperative Banks and Limits of the Financial Strength of Taxes. Annales Universitatis Mariae Curie-Skłodowska, sectio H-Oeconomia, Vol. 54, No. 1.

\footnotetext{
Abstract

The paper deals with the problems of public and legal burdens of cooperative banks operating in Poland, in terms of their limits on the strength of taxes (various types of mandatory fees and levies for the state). Comparative public and legal burdens of banks are discussed in the literature. As the main research goal, the authors chose to examine the situation of cooperative banks in the context of increasing tax and legal burdens. The article uses the desk research method, comparative method and quantitative analysis of cooperative banks' tax burden for calculating the author's tax restrictiveness index. The authors proposed their own definition of the tribute paid by cooperative banks to the state and institutions subordinate to it.
} 
An interesting perspective on the subject of effectiveness of cooperative banks in comparison with their tax burden was analyzed. The paper also exposes the methodology of examining public-law burdens in cooperative banks and conducted a stress limit analysis for these burdens (tributes) on the example of 309 banks - participants of the Association Protection System - SOZ BPS. It is important to point out that the tax restrictiveness index (WD) in the studied group of cooperative banks was calculated. A new concluding case on problems related to further raising the tax burden of cooperative banks in Poland was also presented.

\section{Introduction}

The over-regulation and increase in public and legal burdens of the banking sector after the recent financial crisis also included cooperative banks in Poland. Undoubtedly, the size of the activity, the social mission and the specificity of cooperative banks raises the question whether the cooperative local banking should be equally charged to the state against the principle of proportionality, which is applied in the European Union? José Manuel Barroso, former EC president, stated: "Cooperative banks that have remained faithful to cooperative values and principles and cooperative banks, which rely on members' funds and are controlled by local communities, were able to resist the crisis very well" (Miklaszewska, 2015). However, a wide scope of regulation of the sector and an increase in public and legal burdens encompassed those banks equally. Nevertheless, it is known that small local banks cannot have a higher return on equity than large commercial banks, because their costs are simply higher. The main purpose of the article is to present the methodology of examining public and legal burdens in cooperative banks and to analyze the limit of strength for these burdens (obligatory fees) on the example of 309 banks - participants of the SOZ BPS system (Dec \& Masiukiewicz, 2018; Pasternak-Malicka, 2017).

The main goal of the paper is to present the situation of cooperative banks in the context of increasing tax and legal burdens. The thesis is as follows: the public-legal burdens of Polish cooperative banks are increasingly higher in recent years, approaching the limit of financial strength of taxes from these banks. The authors carried out a quantitative analysis of financial data obtained from several hundred cooperative banks in Poland and proposed an original methodology for calculating the financial strength ratio of tributes in the studied group of cooperative banks.

\section{The public-legal burden of banking in a comparative approach}

Throughout history, taxes were imposed according to the needs of the ruler, without a formal reduction of the tax burden (Brzeziński, 2011). Tax strength and taxation of banks were discussed in numerous scientific works (Wołowiec, 2008; Dec \& Masiukiewicz, 2013; Devereux, Johannesen, \& Vella, 2015; Chaudhry, Mullineux, \& Agarwal, 2015; Gu, de Mooij, \& Poghosyan, 2015; Gajewski, 2016; Schepens, 2016; Buch, Hilberg, \& Tonzer, 2016; Pyka \& Klimontowicz, 2017; Capelle-Blancard \& Havrylchyk, 2017; Cichy, 2017; Piotrowski, 2017; Wiśniewski, 2017; Muszyński, 
2017; Roe \& Troge, 2018; Celerier, Kick, \& Ongena, 2018). On the other hand, the study on charging the fees and taxes of cooperative banks was not a leading area in the literature, but some works in this field can be distinguished (Kata, 2016b; Golec, 2016; Kurkliński, 2018).

It is worth mentioning that if banking activity is accepted as a public good, then the state should protect this sector (Masiukiewicz, 2015b). This also happened during the subprime crisis in the EU and the U.S. The sector's densities should be sustainable in relation to imposed regulatory obligations and tasks, including supporting the country's economy (Kalicki, 2019; Żółtkowski, 2016).Thus, under the concept of public-legal burdens, or a kind of tribute, the authors understand the burden more extensive than only taxes, i.e., also resulting from statutory regulations for banks, e.g., contributions to $\mathrm{BFG}$, contributions from cooperative banks to $\mathrm{SOZ}$ - Association Protection System, Institutional Protection Scheme - IPS (Dec \& Masiukiewicz, 2018) fees on the Polish Financial Supervision Authority and others (Figure 1).

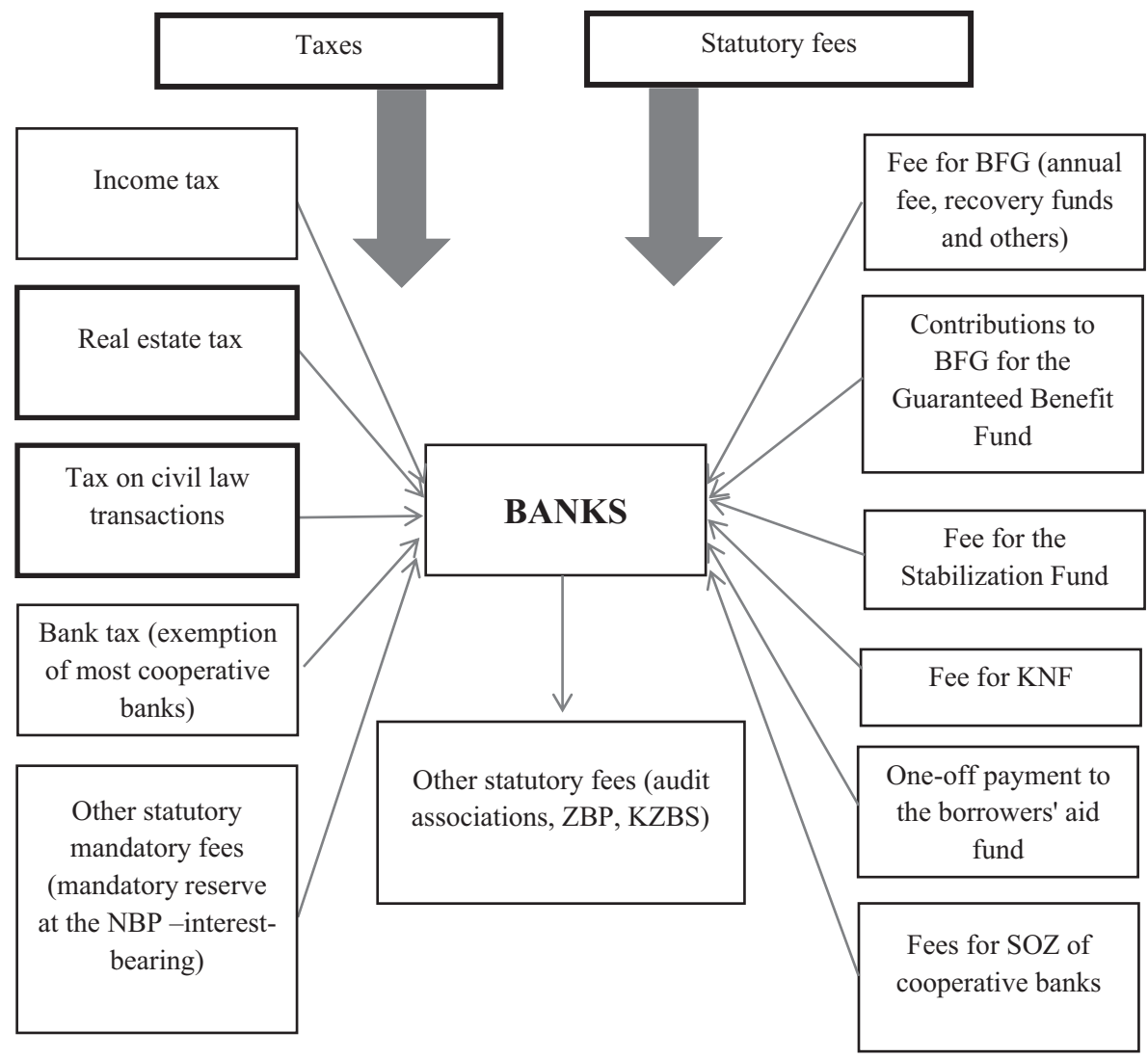

Figure 1. Types of public and legal burdens of cooperative banks 
Remarkably, this definition does not include social insurance contributions and health protection. It was assumed that these are equivalent burdens, closely related to pay and guarantee a specific set of services instead. Thus, the concept of financial strength of tributes incurred by banks was introduced. The capital adequacy ratio and basic tax burden of the banking sector in Poland are presented below, including cooperative banks. The total capital ratio of banks was in 2018 at a good level $(18.9 \%)$, in commercial banks it amounted to $19.0 \%$, and in cooperative banks to $17.1 \%$, but further growth of the business requires capital growth increased in 2018 compared to 2017 by PLN 2.5 billion, or 1.3\% (Pietraszkiewicz, 2019).

Generally, the public and legal burdens of Polish banks (at the level of 38\%) are much higher than in Western Europe (29\%) and the US (above 22\%) - which is not justified by the subprime crisis; which, after all, was not present in Poland (Pietraszkiewicz, 2019). What then is justified, if the ratio of non-performing loans is normal, in the required values?

Curiously, the effects of the new regulations on CHF loans and the MREL directive for bank costs will be significant; although co-operative banks will be affected only slightly (Table 1).

Table 1. Effects of new regulations on CHF loans and the MREL directive

\begin{tabular}{|l|c|c|}
\hline \multicolumn{1}{|c|}{ Banks } & $\begin{array}{c}\text { Present situation of banks by } \\
\text { assets (in PLN millions) }\end{array}$ & $\begin{array}{c}\text { Effects of the CHF and MREL act on the } \\
\text { distribution of banks by assets } \\
\text { (in PLN millions) }\end{array}$ \\
\hline Cooperative banks & $133,113.8$ & $133,113.8$ \\
\hline $\begin{array}{l}\text { Top 8 banks: } \\
\text { - supporting the economy } \\
\text { - with limited } \\
\text { development potential }\end{array}$ & $1,164,138$ & 311,498 \\
\hline Other commercial banks & - & 852,640 \\
\hline Loss-making banks & $496,423.7$ & $496,423.7$ \\
\hline
\end{tabular}

* both cooperative banks and other commercial banks are included in the group of banks with limited development potential

Source: (Pietraszkiewicz, 2019).

Summing up, in recent years there has been a tendency of broad regulation of the banking sector and the introduction of new public-law burdens.

\section{Effectiveness of cooperative banks and public and legal burdens}

It was found that at the end of January 2019, there were 547 cooperative banks operating: 347 associated in BPS SA (308 participating in IPS BPS), 198 associated in SGB-Bank SA (196 participating in IPS SGB) and 2 banks operating independently (KNF, 2019). 
It is crucial to note that the net financial result of cooperative banks decreased compared to September 2017 by $12.1 \%$ (to PLN 544.7 million). Net loss in the total amount of PLN 52.9 million was incurred by 7 banks. Own funds of cooperative banks in the three quarters of 2018 increased by $5.4 \%$ to PLN 12.1 billion (in the entire banking sector own funds increased by $10.7 \%$ ). The total capital ratio of cooperative banks amounted to $17.6 \%$ (against $17.2 \%$ in December 2017), while the Tier I ratio amounted to $16.7 \%$ as compared to $16.3 \%$ in December 2017 (Table 2 ). The increase in total operating income (CPO) in cooperative banks has fallen below the growth rate of costs, and in the case of a slowdown in the economy, the disproportion may deepen.

Table 2. Selected indicators of cooperative banks

\begin{tabular}{|c|c|c|c|c|c|c|c|c|c|c|c|}
\hline $\begin{array}{l}\overrightarrow{0} \\
\stackrel{0}{0} \\
0\end{array}$ & 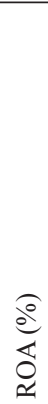 & 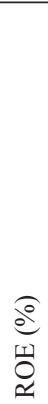 & $\frac{e^{o}}{e^{0}}$ & 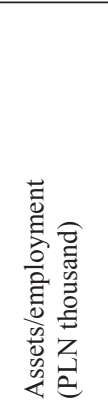 & 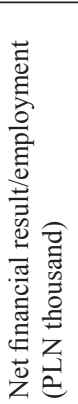 & 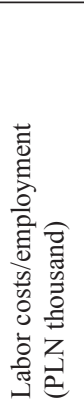 & 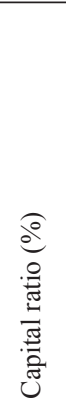 & 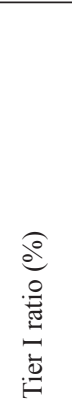 & 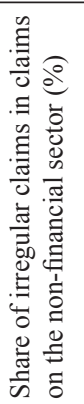 & 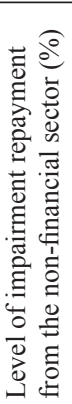 & 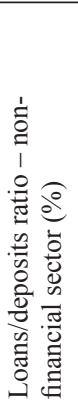 \\
\hline IX 2017 & 0.7 & 6.9 & 65.7 & $3,985.6$ & 26.3 & 64.3 & 17.3 & 16.4 & 8.0 & 32.3 & 64.8 \\
\hline IX 2018 & 0.6 & 6.0 & 68.6 & $4,288.5$ & 23.4 & 67.6 & 17.6 & 16.7 & 8.8 & 42.6 & 61.6 \\
\hline
\end{tabular}

Source: (KNF, 2019).

As far as we know, the maintenance of cooperative banks in a competitive market requires new outlays, among others for IT (Kata, 2016a; Kozłowski, 2015; Kurkliński \& Miklaszewska, 2018). Cooperative banks incur a number of public and legal burdens, both tax and para-tax, mainly included in operating costs (Owsiak, 2013). A significant burden are payments to BFG and fees for $\mathrm{SOZ}$ of associations of cooperative banks, while the payments for the BGF guaranteed fund bear interest and where they will not be paid to the bankrupt bank's clients cannot be treated as a current quasi-tax.

Significantly, the bank tax does not include small banks and credit unions, nor does it include banks that implement remediation programs; what should be assessed positively (Dec \& Masiukiewicz, 2013). However, a few large banks had to pay the tax. Other generally applicable taxes are a tax on civil law transactions, real estate tax (e.g. financial services are exempt from VAT, but all banks pay approximately PLN 2 billion VAT on purchases each year). In addition, banks bear specific burdens, such as reserve requirements at the NBP or, for example, a one-off payment to the borrowers' aid fund. The statutory fees are optional contributions to the audit association and to the chamber of commerce. 
Pobrane z czasopisma Annales H - Oeconomia http://oeconomia.annales.umcs.pl Data: 26/04/2023 13:40:48

PAWEŁ DEC, PIOTR MASIUKIEWICZ

Table 3. VAT payments by the Cooperative Bank in Piaseczno

\begin{tabular}{|c|l|c|c|c|}
\hline No. & \multicolumn{1}{|c|}{ Type } & 2016 & 2017 & 2018 \\
\hline 1 & VAT due & 110,869 & 136,207 & 215,403 \\
\hline 2 & Tax deduction & 77,418 & 3,826 & 146,485 \\
\hline 3 & VAT paid & 33,451 & 132,381 & 68,918 \\
\hline
\end{tabular}

Source: (Data of Cooperative Bank in Piaseczno).

However, cooperative banks pay a small amount of VAT (despite general tax exemption) in connection with purchases; which is illustrated by an example Cooperative Bank in Piaseczno (Table 3).

The specific statutory legal burden for cooperative banks was the depreciation of members' shares; finally, regulations in this area have been modified. In general, the burdens of cooperative banks have increased in recent years. According to Szołno-Koguc (2016) justice is the basis for the construction of a tax system, and the natural limit of taxation is, on the one hand, the state's financial needs, and on the other hand, taxpayers' payment capacities.

\section{The level of burdens and the financial strength of the taxes of cooperative banks}

Laffer's theorem depicts the repayment of public obligations as a curve with a normal distribution (Trabandt \& Uhlig, 2011). In contrast, revenues from rising taxes are approaching zero in an asymptotic way. However, the Laffer curve is not just an economic law, but it can be proved mathematically by Rolle's theorem. An important drawback of the Laffer effect is the passage of time, because the reactions of individual economies to the increase in taxes occur in a longer time horizon, and in the meantime, other factors may influence other tax revenues of the state budget (Gomułowicz \& Małecki, 2013).

Contemporary systems of public-legal burdens (levies) consist not only of taxes, but also a pair of taxes; this applies to financial institutions (Dec \& Masiukiewicz, 2013). Hence the need for a modified model of analysis of these loads. For cooperative banks, the financial tribute strength analysis model should be built as below. The model introduces a category of operating income before payment of taxes (DOPD). Assuming the normal distribution of the Laffer curve, it can be concluded that the WD ratio above $50 \%$ signals excess charges on inputs and thus a decrease in financial strength.

$$
\mathrm{WD}=\frac{\mathrm{PD}+\mathrm{SKNF}+\mathrm{SBFG}+\mathrm{OSOZ}+\mathrm{PN}+\mathrm{OFWK}+\mathrm{PB}}{(\mathrm{DOPD} ; \mathrm{f}:) \mathrm{ZO}+\mathrm{SKNF}+\mathrm{SBFG}+\mathrm{OSOZ}+\mathrm{PN}+\mathrm{OFWK}} \times 100 \%
$$

Where:

WD - tax restrictiveness index, DOPD burden index

DOPD - operating income before the payment of public and legal levies $\mathrm{ZO}$ - operating profit (before PD) 
PD - income tax

SKNF - payment to the Polish Financial Supervision Authority

SBFG - contributions and fees for the Bank Guarantee Fund (including the Stabilization Fund)

OSOZ - payment for the costs of the protection system of the association of cooperative banks

$\mathrm{PN}$ - real estate tax

OFWK - payment for the borrowers' support fund

$\mathrm{PB}$ - bank tax (in principle, exemption for most cooperative banks and credit unions)

In the area of payments to BFG, there have been significant changes since 2018 . Contributions and fees paid to BFG in 2018 included payments to the Bank Guarantee Fund, payments for the Compulsory Fund for Restructuring Banks and other payments to BFG (annual contribution for costs and Stabilization Fund), i.e., without funds for FOŚG (they are at the disposal of banks and they bear interest and payments are incidental, i.e., in the event of bankruptcy of the bank). In the analyzed years, cooperative banks did not pay contributions to the borrowers' support fund. The fee for SOZ BPS applies only to the cost of maintaining the system and does not include payments to the interest-bearing liquidity fund of affiliated banks. In fact, this fee should be reduced by the estimated cost of savings in banks as a result of the takeover of the audit and control function by SOZ BPS.

For the purposes of calculating the financial strength ratio of the WD data, the data of the cooperative banks of the Association of BPS SA for the last three years were adopted; those that created the association protection system (Table 4).

Table 4. Financial strength ratio of cooperative banks' taxes - participants of SOZ BPS in 2016-2018 (308 banks) in PLN

\begin{tabular}{|c|c|c|c|c|}
\hline No. & Type of payment (tribute) & 2016 & 2017 & 2018 \\
\hline 1 & $\mathrm{PD}$ - income tax & $110,420,298$ & $120,585,563$ & $128,931,893$ \\
\hline 2 & $\begin{array}{l}\text { SKNF - payment to the Polish Financial Supervision } \\
\text { Authority* }\end{array}$ & $2,831,512$ & $3,337,249$ & $4,847,159$ \\
\hline 3 & $\begin{array}{l}\text { SBFG - contributions for the Bank Guarantee Fund and } \\
\text { OFS - payment for the Stabilization Fund }\end{array}$ & $41,331,840$ & $33,411,428$ & $46,141,190$ \\
\hline 4 & $\begin{array}{l}\text { OSOZ - payment for the cooperative banks protection } \\
\text { system** }\end{array}$ & $6,204,145$ & $10,534,152$ & $11,849,234$ \\
\hline 5 & $\mathrm{PN}-$ property tax $* * *$ & $6,257,456$ & $6,423,414$ & $11,849,234$ \\
\hline $\mathrm{X}$ & Operating profit (before income tax) & $416,305,044$ & $450,128,573$ & $485,686,724$ \\
\hline
\end{tabular}

The use of the above-described formula allowed to calculate WD - estimated financial strength index of tributes in the studied group of cooperative banks. The results are as follows: 
- $\quad$ WD $(2016)=35.3 \%$

- $\quad W D(2017)=34.6 \%$

- $\mathrm{WD}(2018)=35.7 \%$

The financial strength limit of the taxes of cooperative banks is getting closer (WD is increasing) and conclusions should be drawn from this fact.

\section{Major tax conditions in the future}

Foresight analyzes indicate that Polish cooperative banks may be increasingly burdened with public and legal liabilities. The most important problems in this area are presented below (Masiukiewicz, 2015a; Jaka przyszłość czeka ..., 2016; Kalicki, 2019).

1. New, increased requirements regarding the capital adequacy ratio in the EU. Some cooperative banks have not achieved a higher rate (by 50\%) yet; and it should be achieved in 2019 .

2. Increase in fees for BFG, it was announced at the Banking Forum of the Polish Bank Association Office 2019. For cooperative banks, the payment of some of the fees to the BFG should be maintained (and even increased) in connection with having its own security systems, i.e., Protection Systems of Associations (generating costs) (Ustawa z dnia 10 czerwca 2016 r., 2016; Obwieszczenie Marszałka Sejmu ..., 2018).

3 . There is a need to increase the equity of cooperative banks, related to the development of operations, including the costs of new information technologies and digital security - this is a condition for maintaining the level of competitiveness (Kozłowski, 2015; Kurkliński, 2017). Cooperative banks are also charged with the obligation to depreciate members' shares as a result of the provisions of the EU directive; what is assessed as contradictory to the principles of cooperatives (Czternasty, 2015). On the other hand, lack or low dividend payments also cause a decrease in the number of shareholders in cooperative banks - which is an unfavorable trend.

4. There is a possibility of incurring new fees for the benefit fund for Swiss franc loans in connection with the work on the Act in this respect.

5. The likelihood of introducing a cadastral tax; the risk of increased financial costs of banks operating in their own facilities is rather small.

6. The new tax ordinance draft of 6 October 2017 contains 687 articles to which the codifying committee has submitted 511 pages of justification (Prace Komisji Kodyfikacyjnej..., 2019). One should add about 140 additional changes, which will have to be introduced on the basis of about 40 ordinances. With so much legal uncertainty; resulting primarily from discrepancies in interpretation by the tax authorities themselves and from continuous changes in tax regulations, critical conclusions from surveys conducted among entrepreneurs by the NBP should be taken seriously. A complicated and unfriendly fiscal system may in future not only be a brake on development but also a factor in the degradation of business entities (Podatki i niepewność prawa..., 2019). 


\section{Conclusions}

The level of public and legal levies of cooperative banks has been growing in recent years, as well as the limit of financial strength of taxes has become closer. Decision-makers in matters of the financial market in Poland should learn from this fact. These banks require a further increase in equity for the maintenance and development of lending activities for agriculture and local communities. Therefore, the BFG fees and the fee for the stabilization fund should not be increased, while cooperative banks should be able to recapitalize the Association's protection systems (IPS). It should be considered whether it is reasonable to pay fees to cooperative audit associations in a situation where supervision and control are exercised by: the Polish Financial Supervision Authority, affiliating banks, protection systems of associations and the Supreme Cooperative Council as well as BFG (in special situations). Further increasing the burden on cooperative banks due to state regulation may result in a competitive gap, no dividend payments, fast recourse and the disappearance of this banking sector.

\section{References}

Brzeziński, B. (2011). Relacje między administracją podatkową a podatnikami - od konfrontacji do współpracy. Podatnik versus organ podatkowy, 39.

Buch, C.M., Hilberg, B., \& Tonzer, L. (2016). Taxing banks: An evaluation of the German bank levy. Journal of Banking \& Finance, 72, 52-66. doi:10.1016/j.jbankfin.2016.07.010

Capelle-Blancard, G., \& Havrylchyk, O. (2017). Incidence of bank levy and bank market power. Review of Finance, 21(3), 1023-1046. doi:10.1093/rof/rfw069

Celerier, C., Kick, T.K., \& Ongena, S. (2018). Taxing bank leverage: The effects on bank capital structure, credit supply and risk-taking. Paris December 2018 Finance Meeting EUROFIDAI-AFFI.

Chaudhry, S.M., Mullineux, A., \& Agarwal, N. (2015). Balancing the regulation and taxation of banking. International Review of Financial Analysis, 42, 38-52. doi:10.1016/j.irfa.2015.01.020

Cichy, J. (2017). Sytuacja finansowa polskiego sektora bankowego w warunkach wzrostu obciążeń finansowych i ich wpływ na ratingi banków. Studia Ekonomiczne, 325, 7-19.

Czternasty, W. (2015). Ustrojowe determinanty spółdzielczości. In: E. Mączyńska (red.), Modele ustroju społeczno-gospodarczego. Kontrowersje i dylematy (pp. 343-364). Warszawa: PTE.

Dec, P., \& Masiukiewicz, P. (2018). Model of institutional protection scheme in Polish cooperatives banks. Annales Universitatis Mariae Curie-Skłodowska, Sectio H-Oeconomia, 52(6), $25-35$. doi:10.17951/h.2018.52.6.25-35

Dec, P., \& Masiukiewicz, P. (2013). Podatek bankowy. Warszawa: C.H. Beck.

Devereux, M.P., Johannesen, N., \& Vella, J. (2015). Can taxes tame the banks? Evidence from the European Bank Levies. Sä̈d Business School WP, 5. doi:10.2139/ssrn.2563634

Gajewski, D.J. (2016). Podatek bankowy a zjawisko unikania opodatkowania. Przegląd Ustawodawstwa Gospodarczego, 6, 816.

Golec, M.M. (2016). Regulacje ryzyka działalności kredytowej spółdzielczych kas oszczędnościowo-kredytowych w porównaniu do banków. Finanse, Rynki Finansowe, Ubezpieczenia, 82/4(2), 701-711. doi:10.18276/frfu.2016.4.82/2-61

Gomułowicz, A., \& Małecki, J. (2013). Podatki i prawo podatkowe. Warszawa: Lexis Nexis. 
Gu, G.W., de Mooij, R., \& Poghosyan, T. (2015). Taxation and leverage in international banking. International Tax and Public Finance, 22(2), 177-200. doi:10.1007/s10797-014-9307-2

Jaka przyszłość czeka banki spółdzielcze (2016). Rzeczpospolita, January 31.

Kalicki, K. (2019). Makroekonomiczne i branżowe uwarunkowania szoku regulacyjnego oraz obciążeń daninami publicznymi sektora bankowego. In: L. Kurkliński, B. Lepczyński (red.), Polityka państwa wobec sektora bankowego w Polsce (pp. 51-72). Warszawa: Warszawski Instytut Bankowości, ALTERUM.

Kata, R. (2016a). Konkurencyjność banków spółdzielczych a przekształcenia organizacyjno-biznesowe spółdzielczego sektora bankowego w Polsce. In: M. Poniatowska-Jaksch, R. Sobiecki (red.), Konkurencyjność przedsiębiorstw - aspekty międzynarodowe i sektorowe (pp. 177-200). Warszawa: Oficyna Wydawnicza SGH.

Kata, R. (2016b). Zmiany w mikroekonomicznym i sektorowym modelu bankowości spółdzielczej w Polsce. Roczniki Naukowe Stowarzyszenia Ekonomistów Rolnictwa i Agrobiznesu, 18(4).

KNF (2019, luty). Informacja o sytuacji banków spótdzielczych i zrzeszajacych w trzech kwartałach $2018 \mathrm{r}$. Warszawa.

Kozłowski, Ł. (2015). Wpływ konkurencji ze strony spółdzielczych kas oszczędnościowo-kredytowych na stabilność banków spółdzielczych. Analiza rynków lokalnych. Bezpieczny Bank, 4.

Kurkliński, L., \& Miklaszewska, E. (2017). Modele bankowości spółdzielczej na rynku europejskim i ich ewolucja w okresie pokryzysowym. Wnioski dla Polski. Warszawa: Warszawski Instytut Bankowości, ALTERUM.

Kurkliński, L. (2018). Zagrożenia egzystencjalne obecnego modelu polskiej bankowości spółdzielczej. Prace Naukowe Uniwersytetu Ekonomicznego we Wrocławiu, 531, 289-298.

Masiukiewicz, P. (2015a). Doctrine of public good in banking versus state intervention. Equilibrium. Quarterly Journal of Economics and Economic Policy, 10(1). doi:10.12775/EQUIL.2015.003

Masiukiewicz, P. (2015b). Podatki antykryzysowe. In: S. Owsiak (red.), Determinanty rozwoju Polski. Finanse publiczne. IX Kongres Ekonomistów Polskich. Warszawa: Wydawnictwo PTE.

Miklaszewska, E. (red.). (2015). Małe banki i instytucje okołobankowe w świetle pokryzysowych regulacji. Kraków: Wydawnictwo Uniwersytetu Ekonomicznego.

Miklaszewska, E. (2018). Zmiany strategiczne na europejskim rynku bankowym w okresie pokryzysowym. Warszawa: Poltext.

Muszyński, M. (2017). Podatek bankowy a efektywność działalności operacyjnej banków komercyjnych w Polsce. Finanse i Prawo Finansowe, 3, 81-93.

Obwieszczenie Marszałka Sejmu Rzeczypospolitej Polskiej z dnia 1 marca 2018 r. w sprawie ogłoszenia jednolitego tekstu ustawy o funkcjonowaniu banków spółdzielczych, ich zrzeszaniu się i bankach zrzeszajacych (Dz.U. 2018 poz. 613).

Owsiak, S. (2013). Finanse publiczne. Teoria i praktyka. Warszawa: Wydawnictwo Naukowe PWN.

Pasternak-Malicka, M. (2017). Istota sprawiedliwości podatkowej pionowej i poziomej w kontekście linowej oraz progresywnej stawki podatku dochodowego od osób fizycznych. Finanse, Rynki Finansowe, Ubezpieczenia, 3(87).

Pietraszkiewicz, K. (2019, marzec 14). Wystąpienie na XXV Forum Bankowym. ZBP. Warszawa.

Piotrowski, J. (2017). Podatek od transakcji finansowych. Dylemat wyboru między rozwiązaniem fiskalnym a antykryzysowym. Unia Europejska.pl, 3, 26-36.

Podatki i niepewność prawa największymi barierami rozwoju. (2019). Retrieved from www.mikroekonomia. net/system/publication_files

Prace Komisji Kodyfikacyjnej Ogólnego Prawa Podatkowego. (2019). Retrieved from www.mf.gov.pl

Pyka, A., \& Klimontowicz, M. (2017). Przesłanki zmian modeli biznesowych banków ze szczególnym uwzględnieniem podatku od niektórych instytucji finansowych oraz wymogów kapitałowych. Annales Universitatis Mariae Curie-Skłodowska, Sectio H-Oeconomia, 51(1). doi:10.17951/h.2017.51.1.87

Roe, M.J., \& Troge, M. (2018). Containing systemic risk by taxing banks properly. Yale Journal on Regulation, 35(181). 
Pobrane z czasopisma Annales $\mathrm{H}$ - Oeconomia http://oeconomia.annales.umcs.pl

Data: 26/04/2023 13:40:48

PUBLIC AND LEGAL BURDENS ON COOPERATIVE BANKS AND LIMITS OF THE FINANCIAL STRENGTH..

Schepens, G. (2016). Taxes and bank capital structure. Journal of Financial Economics, 120(3), 585-600. doi:10.1016/j.jfineco.2016.01.015

Szołno-Koguc, J. (2016). Dylematy sprawiedliwości podatkowej - równość i powszechność opodatkowania a przywileje podatkowe. Studia Ekonomiczne. Zeszyty Naukowe Uniwersytetu Ekonomicznego w Katowicach, 294, 164-172.

Trabandt, M., \& Uhlig, H. (2011). The Laffer curve revisited. Journal of Monetary Economics, 58(4), 305-327. doi:10.1016/j.jmoneco.2011.07.003

Ustawa z dnia 10 czerwca 2016 r. o Bankowym Funduszu Gwarancyjnym, systemie gwarantowania depozytów oraz przymusowej restrukturyzacji (Dz.U. 2016 poz. 996).

Wiśniewski, M. (2017). Przerzucalność podatku bankowego w Polsce - próba oceny skali zjawiska. Annales Universitatis Mariae Curie-Skłodowska, Sectio H-Oeconomia, 51(4), 347-355. doi:10.17951/h.2017.51.4.347

Wołowiec, T. (2008). Sprawiedliwość opodatkowania a ekonomiczna efektywność - wybrane aspekty. Studia Prawno-Ekonomiczne, 77, 227-249.

Żółtkowski, W. (2016). Zarządzanie ryzykiem bywa ryzykowne. Nowoczesny Bank Spółdzielczy, 1. 